\title{
Perspectives on Membrane Bioreactor Potential for Treatment of Pulp and Paper Industry Wastewater: A Critical Review
}

\author{
Ali Izadi ${ }^{1}$, Morteza Hosseini ${ }^{*}$, Ghasem Najafpour Darzi ${ }^{1}$, Gholamreza Nabi Bidhendi' ${ }^{2}$, Farshid Pajoum Shariati ${ }^{3}$, \\ Mohammad Reza Mosaddeghi ${ }^{3}$
}

${ }^{1}$ Department of Chemical Engineering, Babol Noshirvani University of Technology, Mazandaran, Iran

${ }^{2}$ Department of Environmental Engineering, University of Tehran, Tehran, Iran

${ }^{3}$ Department of Chemical Engineering, Science and Research Branch, Islamic Azad University, Tehran, Iran

Corresponding Author: Morteza Hosseini, PhD, Associate Professor, Department of Chemical Engineering, Babol Noshirvani University of Technology, Mazandaran, Iran. Email: m.hosseini@nit.ac.ir

Received July 21, 2018; Accepted October 8, 2018; Online Published December 20, 2018

\begin{abstract}
The pulp and paper wastewater contains various organic and inorganic compounds in considerable amounts. Membrane bioreactor (MBR) technology has been used extensively for various industrial wastewater treatments due to its ability to produce appropriate effluent according to water quality regulations. Pulp and paper wastewater can be successfully treated by MBR in different conditions according to the wastewater and MBR characteristics. However, a major drawback in the use of MBR is membrane fouling, which leads to the reduction of effluent permeate flux. Fouling factors need to be considered because they are the major problems affecting the MBR performance. Besides, the performance of MBR can be increased by wastewater pretreatment methods and addition of a fouling reducer. In this paper, the application of aerobic and anaerobic MBR for pulp and paper wastewater treatment and membrane fouling has been reviewed. It has been found that the advantages of MBR over conventional biological treatment processes have made this technology popular for pulp and paper wastewater treatment.

Keywords: Pulp And Paper Wastewater, Membrane Bioreactor, Membrane Fouling, Activated Sludge

Citation: Izadi A, Hosseini M, Najafpour Darzi G, Nabi Bidhendi G, Pajoum Shariati F, Mosaddeghi MR. Perspectives on membrane bioreactor potential for treatment of pulp and paper industry wastewater: a critical review. J Appl Biotechnol Rep. 2018;5(4):139-150. doi:10.29252/ JABR.05.04.02.xx.
\end{abstract}

\section{Introduction}

The wastewater produced by industry has a significant impact on the environment. The pulp and paper industry discharges a huge amount of highly polluted wastewater and is facing challenges to meet stringent environmental regulations. Factories commonly produce great amounts of wastewater, which has a high chemical oxygen demand (COD), toxicity, a low biodegradability and more than 700 organic and inorganic compounds (Table 1) depending on some factors, such as raw material type and production process. There are various special types of pollutants in this wastewater, including lignins, phenols, chlorides, stilbenes, dioxins, furans and sulphur compounds. After primary metals and chemicals industries, the pulp and paper industry produces the third largest amount of wastewater. ${ }^{1-3}$ The water used in pulp and paper factories ranges from $5-100 \mathrm{~m}^{3} / \mathrm{t}$ depending on the characteristics of the raw material, type of produced paper and the value of water reuse. ${ }^{4}$

Contaminants which are produced during process of pulp and paper production can be reduced remarkably by adopting several internal process improvements in combination with management measures. In this respect, European Commission has described the best available techniques to be adopted by pulp and paper factories. Furthermore, several studies have been conducted with the purpose of reduction in the pollution load during the pulp and paper making process. ${ }^{13,14}$

The purpose of this review is to collate the results, data and information from recent research studies performed on the treatment of pulp and paper wastewater using MBR technologies. The results are critically compared and analyzed to establish some important recommendations and conclusions.

\section{The Sources of Wastewater Generation}

Pulp and paper are produced from virgin or recovered fibers as raw materials. Common pulping processes to produce pulp and paper using virgin raw materials include chemical, mechanical, or a combination of both methods, while recovered pulp is produced from fiber recovering processes. Then, the produced pulp is processed using additional non-

Copyright (C) 2018 The Author(s). This is an open-access article distributed under the terms of the Creative Commons Attribution License (http:// creativecommons.org/licenses/by/4.0), which permits unrestricted use, distribution, and reproduction in any medium, provided the original work is properly cited. 
Table 1. Typical Wastewater Characteristics of Pulp and Paper Production Processes

\begin{tabular}{|c|c|c|c|c|c|c|}
\hline Production Processes & $\mathrm{pH}$ & Temp $\left({ }^{\circ} \mathrm{C}\right)$ & $\operatorname{COD}(\mathrm{mg} / \mathrm{L})$ & $\mathrm{BOD}_{5}(\mathrm{mg} / \mathrm{L})$ & TSS (mg/L) & Reference \\
\hline Recycled paper mill & $6.2-7.8$ & $35-45$ & $3380-4930$ & $1650-2565$ & $1900-3138$ & 5 \\
\hline Thermo-mechanical pulping & 4.0-4.2 & $51 \pm 1$ & $3343-4250$ & - & $330-510$ & 6 \\
\hline Paper recycling wastewater & $6.97-7.0$ & - & $430-580$ & $150-200$ & - & 7 \\
\hline Bleaching effluent & 6.9 & - & 1510 & 221 & 354 & 8 \\
\hline Bleaching effluent & 7.3 & - & 1320 & 142 & 452 & 8 \\
\hline Chemical thermo-mechanical pulping & 7.43 & - & 7521 & 3000 & 350 & 9 \\
\hline Pulping process operations & 5.5 & - & 9065 & 2440 & 1309 & 10 \\
\hline Kraft evaporator condensate & 7.0 & $37 \pm 1$ & $2500-2700$ & - & - & 11 \\
\hline Paper pulp for making writing paper & $6.6-10$ & $27-29$ & $490-1114$ & 810-1095 & $40-260$ & 12 \\
\hline Wood yard and chipping & 7 & - & 1275 & 556 & 7150 & 10 \\
\hline
\end{tabular}

fiber materials, such as fillers. ${ }^{15}$

Wastewater of Pulp and Paper Produced From Virgin Fiber Generally, production processes of pulp and paper from virgin fiber can be categorized into pulp making, pulp processing and paper-making. Pulping process begins by debarking, which removes soil, dirt and bark from the wood raw materials and converts the large plant fiber to chips. Afterwards, chips are cooked at high temperature under immense pressure. Moreover, chemical techniques can be used to separate lignin and hemicelluloses from cellulose. This process is usually conducted by means of wet processes, which is responsible for removing large amounts of organic compounds from the wood being processed. ${ }^{10,16}$ The quality of the products in chemical pulping $(\mathrm{CP})$ is significantly high compared with mechanical pulping (MP), but the mechanical process generally produces higher yields. Improvement of MP can be achieved by different methods, such as thermomechanical pulping (TMP), chemo-mechanical pulping (CMP) and chemical thermo-mechanical pulping (CTMP). In TMP method, the raw materials are exposed to pressurized steam. In CTMP, some chemicals such as hydrogen sulfite $\left(\mathrm{HSO}_{3}\right)$ can be added to TMP during the steaming stage for further modifications. ${ }^{17,18}$

The next step which may be used for brown pulp is bleaching process to improve brightness and to allow for paper making operations. Several bleaching agents, such as chlorine dioxide $\left(\mathrm{ClO}_{2}\right)$, hydrogen peroxide $\left(\mathrm{H}_{2} \mathrm{O}_{2}\right)$, ozone $\left(\mathrm{O}_{3}\right)$, etc, which are hardly biodegradable compounds, can be applied. The produced pulp is washed by using an alkali such as caustic soda in order to remove the bleaching agents.,17

Paper-making is the final stage of pulp and paper production, in which the processed pulp is combined with some materials including dyes, resins, fillers such as clay, titanium dioxide, calcium carbonate and sizing agents to form the appropriate paper. Generally, particle size of these materials are in the colloidal range and therefore are difficult to settle during wastewater treatment. ${ }^{3,10,19}$

The volume and specifications of pulp and paper wastewater depend upon production scale, the raw materials and production process. By applying advanced technologies, the amount of water consumed to produce a ton of paper reduced from $500-1000 \mathrm{~m}^{3}$ to $13 \mathrm{~m}^{3} \cdot{ }^{20}$ Generally, wastewater of pulp and paper produced from virgin fiber consists of high levels of biological oxygen demand (BOD) and COD with wood debris and soluble wood materials, various toxic chemicals, such as resin acids, unsaturated fatty acids (such as oleic acids and linoleic acid), di-terpene alcohols, chlorinated resin acids and so on. ${ }^{3,18}$

\section{Wastewater of Pulp and Paper Produced From Recovered Fibers}

Recently, recycling of waste papers such as mixed office waste, old newsprint and old corrugated container has been increasingly used because of environmental and economic benefits. Saving natural resources and reducing solid waste generation can be mentioned as the main reasons of such recycling methods. ${ }^{21}$

Fiber recovery can be mainly classified into pulping process, high density screening and deinking steps. Pulping is generally used to convert the waste paper into the recovered fibers dispersed in water and to prepare them for deinking, which removes the ink particles from cellulose fibers. Screening eliminates large particles with high and medium density, such as paper clips and staples. Deinking can be considered as the main step of the recovered fibers recycling process, which chiefly consists of separating of ink particles from the cellulose fibers by washing those of less than $25 \mathrm{~mm}$ diameter or floating larger particles such as toner inks and laser printed papers. ${ }^{22,23}$ Toxic substances, such as $\mathrm{H}_{2} \mathrm{O}_{2}, \mathrm{NaOH}, \mathrm{Na}_{2} \mathrm{SiO}_{3}$, $\mathrm{Na}_{2} \mathrm{CO}_{3}$ and other compounds are currently used as chemical deinking agents with the purpose of brightness improvement of the recycled pulp. ${ }^{24}$

Generally, impurities such as sand, glass, plastic, coatings and fillers are separated from waste papers during recycling process. In addition, high concentrations of surfactants in paints and printing ink can be released into the wastewater during paper recycling process. Furthermore, pollutants such as CP additives including caustic soda, sodium silicate and hydrogen peroxide, deinking additives, ink particles and other impurities such as fines and fillers are normally produced in fiber recycling mills. ${ }^{25,26}$ Therefore, paperrecycling wastewater is a complex mixture including toxic and recalcitrant substances, indicating complexity and difficulty 
of treatment process. ${ }^{27}$

Pulp and Paper Industry Wastewater Treatment Technologies Regardless of various wastewater treatment techniques, such pollutants mentioned earlier have been found in the final treated effluents due to incomplete degradation and economic limitations of some effective pulp and paper wastewater treatment techniques. ${ }^{28}$ In an overall view, pulp and paper wastewater treatment techniques are divided into physicochemical and biological treatment methods. Physicochemical treatment methods, such as coagulationflocculation, reverse osmosis (RO), adsorption and oxidation have been well used because of their performance in the removal of a variety of contaminants from the pulp and paper wastewater. Generally, biological treatment methods consisting of microorganisms including bacteria, fungi, algae and enzymes have been coupled with other physicochemical methods. Biological methods compared with physicochemical wastewater treatment methods are considered to be cost effective and ecofriendly. However, the conventional biological processes have not been effectively performed for removing color and recalcitrant compounds from pulp and paper mill wastewater. ${ }^{15,29,30}$ Various toxic chemicals such as resin acids, unsaturated fatty acids, alcohols and chlorinated resin acids are produced in the pulp and paper industry, and therefore, this variety of pollutants provide a significant challenge for traditional biological treatment such as activated sludge (AS). For this reason, MBR processes are being used in the pulp and paper wastewater treatment in order to gain high quality effluent to meet stringent regulations and also to reuse the effluent. ${ }^{31-33}$ Table 2 shows the performance of aerobic, anaerobic and hybrid treatment processes for different types of pulp and paper wastewater.

\section{MBR Processes}

MBR systems essentially consist of a combination of biological reactor coupled with membrane units for biodegradation and physical separation of the waste compounds. The first reported application of membrane reactor was in 1969, when an ultrafiltration membrane was used to separate AS from the effluent of a biological wastewater treatment system. ${ }^{35}$ This technology can produce clarified, high-quality and largely disinfected effluent, offering the possibility of water reclamation. It has been used for treating many kinds of wastewater, such as municipal, ${ }^{36-39}$ high strength wastewater, ${ }^{40-42}$ food industry, ${ }^{43,44}$ pharmaceutical, ${ }^{45-47}$ tannery ${ }^{48,49}$ and other types of wastewater.

There are two types of operations, namely cross-flow and

Table 2. Performance of Different Aerobic, Anaerobic and Hybrid Processes in the Pulp And Paper Wastewater Treatment

\begin{tabular}{|c|c|c|c|c|}
\hline \multirow{2}{*}{ Treatment Process } & \multirow{2}{*}{ Source of Wastewater } & \multicolumn{3}{|c|}{ Contaminants Removal Efficiency (\%) } \\
\hline & & COD & Color & Other Compounds \\
\hline \multicolumn{5}{|c|}{ Aerobic Systems } \\
\hline \multirow[t]{2}{*}{ Activated Sludge } & Kraft pulp mill & 60 & 40 & 36 (Tannin and Lignin) \\
\hline & Integrated pulp mill & $60-70$ & - & 60 (TOC) \\
\hline Multiple stage & Black liquor & 65 & - & - \\
\hline \multirow[t]{2}{*}{ ASB } & Kraft pulp mill & 67 & - & - \\
\hline & Kraft pulp mill & 40 & - & - \\
\hline \multirow[t]{2}{*}{ SBR } & Paper mill & 75 & - & - \\
\hline & Hardwood Kraft mill & 69 & - & $>80$ (TSS) \\
\hline Bio-filter & TMP & 52 & - & - \\
\hline \multirow[t]{2}{*}{ Membrane bioreactor } & Paper mill & 80 & - & >90 (TSS) \\
\hline & Paper mill & 92 & - & 84 (Ammonia), >99 (TSS) \\
\hline Facultative stabilization basin & Kraft mill & 62 & - & 51 (AOX), 69 (Chlorinated compounds) \\
\hline \multicolumn{5}{|c|}{ Anaerobic Systems } \\
\hline \multirow[t]{5}{*}{ UASB } & Kraft pulp mill & 79 & $\approx 0$ & 71-99.7 (Chlorinated compounds) \\
\hline & Paper mill & 66 & - & 73 (Sulphate) \\
\hline & Bagasse wash & $80-85$ & - & - \\
\hline & TMP & 73 & 45 & - \\
\hline & Pulping whitewater & $65-70$ & - & 90 (TSS) \\
\hline Up-flow anaerobic filter & Bleaching process & 50 & & $88(\mathrm{AOX})$ \\
\hline Two step anaerobic bio-reactor & Paper mill & 88 & 95 & 67 (AOX), 86 (Lignin), 63 (Phenol) \\
\hline \multicolumn{5}{|c|}{ Hybrid Systems } \\
\hline UASB + electrochemical & Kraft pulp mill & 93 & 96 & - \\
\hline AS + hydrogenation & Kraft pulp mill & 95 & 97.5 & 97 (TSS) \\
\hline UASB + aerobic reactor & Black liquor & 72 & 57 & - \\
\hline SBR + ozone treatment & Kraft pulp mill & $40-70$ & Clear & 46 (Lignin) \\
\hline $\mathrm{FBR}+$ poly-electrolyte & Black liquor & 78 & 81 & 60 (TSS) \\
\hline Anaerobic + aerobic + ozonation & White liquor and Black liquor & 83 & 95 & - \\
\hline
\end{tabular}

Source: Ashrafi et al. ${ }^{34}$ 
dead-end, which have been shown in Figure 1(a) and (b). These operations need to be performed in the presence of pressure drive. Basically, cross-flow filtration is carried out by using hollow fiber (HF), flat sheet (FS) or multi tubular (MT). This type of filtration can reduce the formatting of the cake layer on the surface of the membrane. In dead-end operation, the solids from the feed, which are larger than the pore size, are easier to accumulation on the membrane surface, and generally, this type of filtration is in batch process. ${ }^{50}$

Generally, configurations of MBR systems are external/ side-stream, submerged/immersed and airlift as shown in Figure 2. In external configuration, membrane module is placed outside the bioreactor and consists of the mixed liquor recirculation through a membrane module (Figure 2a). This configuration provides more direct hydrodynamic control of membrane fouling and has the advantages of easier membrane replacement and high fluxes. ${ }^{52,53}$

In submerged configuration, membrane modules are in the mixed liquor and the driving force across the membrane is provided by creating negative pressure on the permeate side (Figure 2b). Some advantages of submerged MBR include its much lower energy consumption and less rigorous cleaning procedure. ${ }^{54,55}$ One of the latest MBR configurations is airlift side stream MBR. The concept applies the side-stream airlift principle using a reliable side stream configuration while incorporating all the advantages of the submerged systems

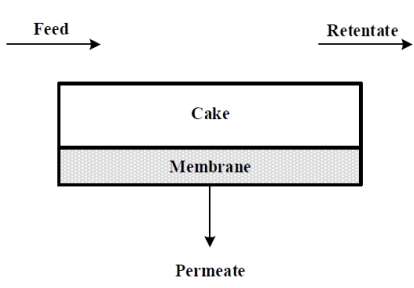

(a)

Figure 1. (a) Cross-Flow Filtration and (b) Dead-End Filtration. ${ }^{5}$

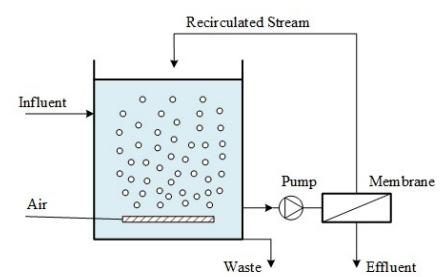

(a)

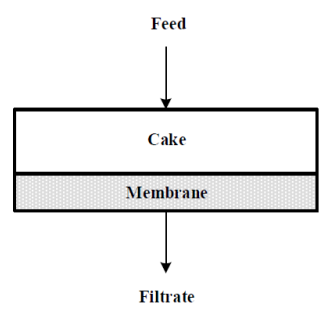

(b)

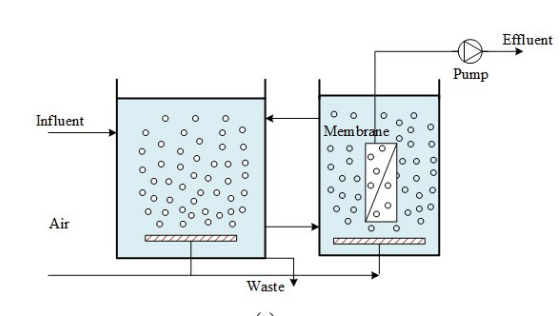

(c)

Figure 2. Configurations of Membrane Bioreactor: (a) External Configuration, (b) Submerged Configuration, (c) Airlift Configuration.
(Figure 2c). ${ }^{56,57}$

Furthermore, in recent years, some new advanced MBR configurations have been used, which own various advantages. For example, draft tube internal loop airlift bioreactor has been used for hydrodynamic investigations and oxygen transfer behavior of water in diesel micro emulsions. ${ }^{58}$ An external loop airlift membrane bioreactor (ELAMBR) was used for pharmaceutical wastewater treatment and its performance was analyzed. The long-term stability of operational system and the effects of solids retention time (SRT) on the contaminant removal efficiency were studied. The results showed that the initial concentration of the contaminants, COD and mixed liquor suspended solids (MLSS) are the most effective parameters in removal of pollutants. ELAMBR had advantages such as simple operation and maintenance, efficient removal of pollutant and low-energy consumption. ${ }^{59}$

In addition, an MBR has been used as a pretreatment step before $\mathrm{RO}$ in order to reuse industrial town wastewater. The results indicated that MBR produces a high quality permeate water. Approximately, 75\%, $98 \%$ and $74 \%$ removal of COD, TSS and TN were recorded respectively and also silt density index of the permeate effluent was below 3 most of the time. ${ }^{60}$ The hybrid electro membrane bioreactor (HEMBR) was used for pretreatment of RO and advanced treatment of effluent by simultaneous integration electrical coagulation with an MBR. Results demonstrated that suspended solids (SS) removal efficiency is almost $100 \%$ for HEMBR and MBR. HEMBR removal of COD improved by $4 \%$ and membrane fouling was reduced according to transmembrane pressure (TMP). The silt density index of HEMBR permeate samples was slightly better, indicating less $\mathrm{RO}$ membrane fouling. Furthermore, according to the SVI comparison of MBR and HEMBR biomass samples, HEMBR showed better settling characteristics, enhancing the dewaterability and filterability of the sludge. ${ }^{61}$

An innovative MBR consisting of two anoxic bioreactors followed by an aerated MBR, UV unit and a granular activated carbon (GAC) filter were applied for the treatment of dye. Once the biological system was adapted, $95 \%$ of dye, $99 \%$ of COD, $97 \%$ of nitrogen and $73 \%$ of phosphorus were removed at a retention time of 74.4 hours. Moreover, for complete dye removing, MBR effluent was passed through the UV-unit and GAC filter. ${ }^{62}$ The SMB-OsMBR hybrid system, combining of sponge-based moving bed (SMB) and an osmotic MBR (OsMBR) were studied using Triton X-114 surfactant coupled with $\mathrm{MgCl}_{2}$ salt as the draw solution. In comparison with OsMBR, the SMB-OsMBR system due to the thick-biofilm layer on sponge carriers was able to remove more nutrients and less membrane fouling was observed. The nutrient removal efficiency of the proposed system was close to $100 \%$, confirming the effectiveness of simultaneous nitrification and denitrification in the biofilm layer on sponge carriers. ${ }^{63}$

\section{Membrane Characteristics}

Generally, membrane performance relates to the size of membrane pores, membrane materials, MBR processes configuration, wastewater type, solubility and retention time. Retention occurs due to the concentration change between 
the retentate and permeates. The important parameters in MBR operation are permeability, flux, TMP and resistance. Permeability is defined as flux per pressure $(\mathrm{J} / \Delta \mathrm{P})$ or $\mathrm{LMH} /$ $\Delta \mathrm{kPa}$. Flux $(\mathrm{LMH})$ is the permeate flow per unit area of membrane and depends on hydraulic resistance, thickness of the membrane or cake layer and driving force. Driving force is the gradient of membrane potential area of mass transport involving pressure and concentration of particles. The mass transport mechanism for the membrane depends on the materials and structure of the membrane. ${ }^{64}$

The size of contaminants is an effective parameter in the selection of membrane type. Generally, microfiltration (MF) is used for removing suspended solids with the particle size in the range of 100-1000 nm, ultrafiltration (UF) for a particle with 5-100 nm size and nanofiltration (NF) for particles with 1-5 nm size. Most of the treatment plants use MF or UF regarding the fouling and cost factors. ${ }^{52,65,66}$

Polymers and ceramics are two types of materials that are chiefly used to construct the membranes. Generally, ceramic membranes have higher hydrophilic ability and a good performance in filtration compared to polymeric ones due to their high chemical resistance, inertness and easiness of cleaning, and are applied in industrial wastewater treatment; however, they suffer some drawbacks including expensive fabrication and fragility. ${ }^{67,68}$

Suitable polymeric materials which have been widely used include polyvinylidene difluoride (PVDF), polyethersulfone (PES), polyethylene (PE) and polypropylene (PP) because of appropriate physical and chemical resistance. PVDF is the most prevalent membrane material, accounting for almost half of all products, and provided both in FS and HF configurations. PES, PE and PP membranes were also found to be available in FS and HF configurations respectively. Although polymeric membranes enjoy some advantages, being easy to foul is their weakness, which is associated with their hydrophobic characteristic. However, the hydrophobic membrane weakness can be improved by coating the membrane using hydrophilic materials. ${ }^{52,69,70}$

MBR for the Treatment of Pulp and Paper Industry Wastewater The pollution of land, water and air is an important problem caused by rapid growth of population and the demand for industrial establishments to fulfill human requirements. It has been estimated that the pulp and paper industry is responsible for $50 \%$ of all wastes dumped into the environment. In pulp and paper industry, water recycling has been emphasized due to the massive amount of water consumed. The treatment of pulp and paper wastewater by conventional methods, such as coagulation and AS process contains various nonbiodegradable organics, inorganic and color materials and therefore, the effluent quality does not meet the regulations. ${ }^{18}$

Regarding high temperature of pulp and paper wastewater $\left(50-70^{\circ} \mathrm{C}\right)$, thermophilic treatment was used for energy saving and reduction of operational costs. Several studies have been conducted to compare the performances of thermophilic treatment with mesophilic treatment. The results showed that thermophilic treatment can produce comparable permeate quality. ${ }^{32,71}$ An integrated thermophilic submerged aerobic membrane bioreactor (TSAMBR) and electrochemical oxidation (EO) technology were developed for TMP treatment. Cake formation was identified as the dominant mechanism of membrane fouling. The EO of the TSAMBR permeate was performed and a complete decolorization was achieved. The COD removal efficiency increased to about 96.2-98.2\%. Results illustrated that the high-quality effluent produced by the TSAMBR-EO system can be reused as process water for system closure in pulp and paper mill. ${ }^{6}$ An application of submerged FS MBR modules to treat circuit wastewater from the paper industry was evaluated. The thermophilic MBR process showed to be reliable for use as in-mill technology for wastewater reuse in the pulp and paper industry. ${ }^{72}$ In general, the higher temperature results in higher substrate degradation rates because of faster reaction kinetics and increase of specific biomass growth rates and a lower net sludge yield is observed due to an increased endogenous respiration rate of the microorganisms. The poor sludge settleability is one of the main drawbacks of this technique. It is assumed that the reason was the difference in the species of microorganisms, especially a greater number of filamentous bacteria in the population. ${ }^{73,74}$

Recently, usage of membrane separation technology, as an alternative way for the treatment of the paper mill wastewater, has attracted attention because of energy efficiency, footprint reduction and simple operation. Many reports have demonstrated the application of membrane technology in the wastewater treatment of pulp and paper mills. ${ }^{75}$

\section{Application of Aerobic MBR}

An ultrafiltration system and an external membrane bioreactor were applied to compare TSS, TDS and COD removal efficiencies for mechanical newsprint mill wastewater. In all cases, the MBR had higher removal efficiencies than the ultrafiltration system. The MBR demonstrated 48-58\% removal of total COD, 35\%-45\% removal of dissolved COD, $25 \%-35 \%$ removal of total solids (TS) and $20-30 \%$ removal of TDS. ${ }^{76}$

Foul condensates from kraft pulp mills were treated in an immersed membrane bioreactor which was fed continuously and total reduced sulphur and methanol removals were obtained in the mesophilic temperature range. As the temperature increased, a reduction in efficiency was observed. The results showed that the treatment of kraft pulp mill foul condensates at high temperatures using a membrane bioreactor could be technically feasible and has good potential for industrial application. ${ }^{32}$ Wastewater of the paper industry was affected by integrated treatment consisting of MBR and an oxidation step. Screening tests with different types of oxidation showed that ozonation after biological treatment could reduce the COD by $40 \%$ and BOD/COD ratio could be increased up to 0.19 . Based on results, an integrated treatment system was designed with recirculation of MBR effluent during ozonation. The economic evaluation showed that the integrated chemical and biological treatment is costly for the pulp and paper industry. ${ }^{77}$ The treatment of paper mill wastewater by MBR system in order to obtain high quality effluent for sustainable reclamation and reuse was studied. 
Results showed that the COD and BOD reduction was $86 \%$ and $98 \%$ respectively. In addition, both TKN and ammonia was reduced by $90 \%$ and the TSS in the effluent was always lower than $5 \mathrm{mg} / \mathrm{L} .^{78,79}$

\section{Application of Anaerobic MBR}

The study has been done on a full-scale AS plant compared to an MBR with flat sheets membranes. Both systems received their feed from an anaerobic bioreactor treating paper mill wastewater. MBR produced an effluent with higher quality than AS in terms of SS. Other effluent quality specifications, such as organic matter, phosphorus and nitrogen compounds, did not show substantial differences between AS and MBR. Fouling due to calcium carbonate scaling and formation of biofilm layer on the membrane caused high reduction of flux and therefore required proper and more complicated maintenance than the AS system. The results showed that, for paper mill wastewater, after anaerobic biotreatment, if there is no need for excellent effluent quality in terms of suspended solids, the replacement of the AS by the MBR would not be strongly justified, mainly because of maintenance cost. ${ }^{33}$

A study on the thermophilic anaerobic digestion of highstrength kraft pulp wastewater has been performed. The system consisted of an MF membrane module for oily substances removal, a stripping system for removal of sulfur compounds, an anaerobic packed fixed-bed bioreactor with pumice stone for methane fermentation and an UF membrane module for retention of a high density of microorganisms. In a continuous run with only the MF membrane module for oily substances removal, the digester efficiency decreased because of methanogenic inhibition by sulfur compounds. After fitting the stripping system which used evolved gas from the digester, more than $80 \%$ of the inhibitive sulfur compounds were removed and high loading and high efficiency operation could be reached. ${ }^{80}$

The external AnMBRs for pulp and paper wastewater treatment was used, which provided an excellent quality permeate for reuse and eliminated the impact of sludge deflocculation on the quality of treated effluent. It appears that submerged AnMBR technology has a bright future for pulp and paper effluent treatment to recover energy and achieve closed cycle operation and therefor lower cost than aerobic treatments. ${ }^{81}$

The effects of $\mathrm{pH}$ on the MBR performance and membrane fouling of a submerged anaerobic membrane bioreactor treating thermo mechanical pulping wastewater were investigated. Changes in COD removal, biogas production, sludge and cake layer properties and their correlations on membrane fouling were investigated before and after $\mathrm{pH}$ shocks. The results showed that a $\mathrm{pH} 8.0$ shock had a low impact, while $\mathrm{pH} 9.1$ and 10.0 shocks exerted significant long-lasting negative impacts on COD removal, biogas production and membrane filtration performance. The elevated $\mathrm{pH}$ shocks induced the dispersion of sludge flocs and resulted in the collection of colloids and biopolymers in the sludge suspension and thus declined membrane performance. Statistical analysis showed that the ratio of proteins to polysaccharides in extracellular polymeric substances (EPS) had a negative effect on the membrane fouling rate. There were smaller size particles deposited on the membrane surface and a more compact and denser cake layer was formed after being exposed to an alkaline shock at $\mathrm{pH} 10$, resulting in higher membrane fouling rates. ${ }^{82}$

\section{MBR Fouling Evaluation}

Membrane fouling in wastewater treatment processes, such as MBR system, can be generally characterized as initial pore clogging followed by foulant layer formation. Foulant layer can be further distinguished as gel layer and cake layer. It was reported that gel layer is formed from the gelation of the colloidal and dissolved materials, and in many cases, the gelling foulants were the main contributors to membrane fouling. ${ }^{83-85}$ In the biological process, EPS are released by microorganisms during substrate metabolism, biomass growth and biomass decay. Main factor related to MBR fouling is EPS and then these organic molecules deposit onto the membrane surface and these organics are generally forming a colloidal layer on the membrane. ${ }^{86} \mathrm{~A}$ low concentration of EPS in inlet wastewater might have negative impact on MBR performance for floc decomposition, and therefore, a minimum amount of EPS should be available in the wastewater for sustainable performance of MBR process. ${ }^{87}$ Studies depicted organic substances caused increase in sludge viscosity and therefore increase in filtration resistance, which is attributed to the attachment of EPS onto the membrane surface. EPS is generally categorized into two types, namely bound and soluble EPS. Bound EPS involves capsules, sheaths, loosely bound polymers and attached organic materials and soluble EPS is referred to soluble microbial products (SMPs), which mainly consists of low to high molecular weight proteins, protein-like substances, polysaccharides and polysaccharidelike substances. Generally, SMPs deposit on the membrane and therefore block the membrane pores or make a cake layer on the membrane surface and also increase the hydraulic resistance. ${ }^{88-90}$ The effects of EPS on the AS rheology were investigated in a submerged membrane bioreactor operated at different SRT values and different carbon to nitrogen ratios $(\mathrm{C} / \mathrm{N})$ of feed wastewater. Operational parameters such as MLSS, protein fraction of EPS (EPS $)$, carbohydrate fraction of EPS (EPS $)$, protein fraction of SMP $\left(\mathrm{SMP}_{\mathrm{p}}\right)$, carbohydrate fraction of SMP (SMP), apparent viscosity, critical flux and hydrophobicity in mixed liquor and their correlations were investigated. The results showed that the $\mathrm{C} / \mathrm{N}$ ratio of feed, SRT, MLSS and SMP were found to have positive effects on apparent viscosity at 3 different shear rates. On the other hand, a negative effect was detected between the apparent viscosities and the critical fluxes. It was also observed that there is a significant positive correlation between hydrophobicity and both EPS $_{\mathrm{p}}$ and $\mathrm{SMP}_{\mathrm{p}}{ }^{91}$

Critical flux is a value of flux that exists as irreversible deposit and there is no fouling below the critical flux. Critical flux happens when a thick cake layer forms on the membrane and fouling could happen when the flux is above critical flux. With regard to critical flux, the suitable flux for the operation 
can be defined based on the TMP sustainability.92 The deposition of biopolymers on the membrane surface could change the specification of the membrane and then cause severe membrane fouling and also increasing of biopolymer concentration in sludge suspension. This could increase the viscosity and effectively make a barrier for the permeation. ${ }^{93}$

Studies have also showed a direct effect of carbohydrate concentrations on MBR fouling and it was found that carbohydrate molecules had a higher fouling propensity than protein molecules. This was associated with the hydrophobic and smaller size of protein molecules compered to carbohydrate. ${ }^{94}$

Membrane fouling was investigated in a novel airlift oxidation ditch membrane bioreactor (AOXMBR) working under various OLRs. The results showed the high performance of AOXMBR in terms of COD removal, even at very high OLRs. In addition, the study confirmed that the performance of the AOXMBR was better in comparison with the conventional AS. Moreover, on-line viability measurement of the AS showed that the fouling increased with reducing AS viability. The results illustrated that the qualitative change of the AS affected the membrane fouling. The membrane fouling dynamics analysis showed the relationship between the reason of membrane fouling and MBR operating condition. Adsorption in pores appeared to be the dominant reason when biofilm or deposit was not available on the membrane surface. ${ }^{95}$

AnMBR, compared to aerobic MBR, has higher propensity to foul and therefore, requires a long SRT which could lead to worse internal pore blocking possibly for higher concentrations of responsible foulants, such as protein and carbohydrate molecules in SMPs. ${ }^{96}$ Since SRT controls the MLSS concentration, it has an effect on membrane fouling. Generally, longer SRT in MBR system assists in increasing the MLSS concentration and thereby, reduces the biotreatment tank size and promotes the development of specific nitrifying bacteria. However, the efficiency of oxygen transfer rate decreases exponentially with concentration of MLSS. ${ }^{97-99}$ It has been clarified that high concentrations of MLSS are related to the high viscosity of mixed liquor and therefor significantly contribute to the membrane fouling. In addition, longer SRT leads to producing a higher concentration of protein and carbohydrate molecules in SMP and subsequently increasing the membrane fouling. ${ }^{100,101}$

The total hydraulic membrane resistance $\left(\mathrm{R}_{\mathrm{t}}\right)$ was calculated according to Darcy law (Eq. 1):

$R_{t}=\Delta P /\left(J \cdot \mu_{p}\right)$

Where $\Delta \mathrm{P}, \mu_{p}$ and $J$ are the TMP, permeate dynamic viscosity and the constant permeate flux, respectively. A common approach is to interpret the overall resistance $R_{t}$ as the sum of 4 individual resistances, all of which depend on time and experimental conditions. The expression can be explained as (Eq. 2):

$R_{t}=R_{m}+R_{p}+R_{c}+R_{f}$
$\mathrm{R}_{\mathrm{m}}$ is the clean membrane resistance, $\mathrm{R}_{\mathrm{p}}$ is the hydraulic resistance attributed to pore blocking, $R_{c}$ is the hydraulic resistance attributed to the cake layer and $R_{f}$ is the resistances caused by concentration polarization.

The values of these different resistances were obtained after specific membrane cleaning procedures. The method of measuring the membrane resistances is as follows: the flux and TMP of the new membrane module in tap water are measured before the MBR operation. Then, $R m$ is obtained from Eq. $(1,2)$ after the MBR operation, the flux and the TMP of the membrane module are measured leading to calculation of Rt. The module is submerged in tap water for calculation of $R_{c}+R_{p}+R_{m}$. Then the module was rinsed under tap water to calculate $R_{p}+R_{m}{ }^{95}$

A lab-scale filtration cell was used to find out the optimum relaxation time for MBR membranes. The sludge obtained from several plants was analyzed with fixed filtration times and intermittent relaxations of decreasing durations. Test on the lab-scale filtration cell and a pilot MBR showed that the highest net flux was obtained with the same relaxation time, which indicates that the lab-scale filtration cell can be used to optimize the relaxation time in large-scale MBR systems. The permeate flux was obviously higher in the lab-scale filtration cell than the MBR system due to irreversible fouling in the pilot MBR. Mathematical simulations indicated that approximately $85 \%$ of the membrane area in the pilot MBR plant was blocked during operation. The results revealed that the lab-scale filtration cell can be applied independently to check both sludge filterability and membrane condition in full-scale MBR systems, and the optimal relaxation time for large-scale MBRs can be determined in lab-scale systems. ${ }^{102}$

MBR was continuously operated to investigate fouling mechanisms caused by gel layer formation. Agar was applied as a model foulant for gel layer formation, and filtration resistance of gel layers was evaluated. The results illustrated that gel layer possessed unusually high specific filtration resistance and high measured porosity compared with cake layer. A new fouling mechanism based on Flory-Huggins theory was proposed. Filtration resistance of agar gel layer was discovered to be independent from $\mathrm{pH}$ and ionic strength, but linearly increase with gel thickness. Simulation of the mechanism model showed that the filtration resistance induced by mixing chemical potential variation was comparable to experimental data of filtration resistance of gel layer, indicating that the proposed mechanism is the predominant one responsible for the high filtration resistance of gel layer ${ }^{103}$. A new model was also proposed as a numerical tool to predict the deposit mass composition of SS and SMP on the membrane surface in an AnMBR. This approach offered interesting perspectives for fouling prediction and the on-line control of an AnMBR process. ${ }^{104}$

\section{Control of MBR}

Generally, the process control of MBR is a complicated task because the biological performance can be affected by type of wastewater, membrane selectivity and operating conditions, such as SRT, HRT, F/M ratio and membrane permeate flux. 
The performance of treatment process is related to microbial quantity and quality. Therefore, application of a suitable method for monitoring these microbial key parameters is critical to effective treatment of wastewater. ${ }^{105,106}$

Considering cells viability and reactivity concepts, more information on the state and nature of AS could be obtained. The usage of an on-line capacitance sensor for obtaining information about the biological state of the AS in an MBR was successfully investigated. Determination of MLSS or MLVSS in AS systems is not really a good indicator of the biological state of the process, and therefore, the quality of cells should also be considered. The preliminary results on biomass monitoring of AS by a capacitive sensor are in favor of its application in wastewater treatment plants. ${ }^{107}$

There are some methods for controlling MBR process and its fouling prevention, for instance, coagulation as a pretreatment method and sufficient aeration can improve the aerobic MBR performance and thus reduce the membrane fouling. ${ }^{108-110}$ Coagulation is a necessary pretreatment step to remove micro-particles in aqueous suspension before a conventional sedimentation and a membrane filtration. ${ }^{111}$ Polyaluminium chloride coagulant has been compared with other adsorbents, such as powdered activated carbon (PAC), zeolite and polyamide. Results showed that coagulant, compared to mentioned adsorbents, considerably decreased the membrane fouling. ${ }^{112}$ The flocculation performances of nine cationic and anionic polyacrylamides with different molecular weights and charge densities in the pretreatment of pulp and paper mill wastewater have been investigated. Based on the cost evaluation, the use of the polyacrylamides is economically feasible to treat the pulp and paper mill wastewater. This result suggests that single polymer system can be used alone in the coagulation-flocculation process due to the efficiency of the polyacrylamide ${ }^{113}$. The flocculation performances of polydiallyldimethylammonium chloride with different molecular weight in the treatment of pulp and paper mill wastewater were evaluated. The effectiveness of the flocculation was measured based on the reduction of the turbidity, TSS, COD and zeta potential measurements. Results illustrated that the flocculation performance of higher molecular weight samples was more efficient compared with that of lower molecular weights. This might be due to the bridging mechanism, which occurred concurrently with the charge neutralization effect during flocculation. ${ }^{114}$ The hybrid PAC-MBR system decreased the amount of membrane fouling and steadily increased the removal performance of etodolac. PAC addition reduced the deposition of EPS and organic matter on the membrane surface and resulted in an increase in COD removal, even at higher OLRs with low PAC addition. Membrane fouling mechanisms were evaluated using combined adsorption fouling models. Modified fouling index values and normalized mass transfer coefficient values indicated that cake adsorption was the predominant fouling mechanism. ${ }^{115}$ The effect of PAC on fouling reduction in anaerobic MBR has been analyzed, and it has been reported that the performance of membrane in anaerobic MBR was enhanced after PAC addition. The mechanism of PAC for fouling reduction was due to adsorption of solutes and colloids in the supernatant and enlarged floc size due to incorporation of PAC into the bioflocs. Nevertheless, it has also been found that the PAC overdose could become a foulant and led to an increase in the membrane fouling. ${ }^{116}$ The effect of PAC and GAC on the performance of anaerobic MBR systems has been investigated. Results showed the addition of PAC compared to GAC led to greater removal of COD due to the higher surface area of PAC. ${ }^{117}$

\section{Industrial Applications and Economic Investigation}

It was predicted that, by 2019 , more than 5 million $\mathrm{m}^{3} / \mathrm{d}$ of wastewater would be treated by MBR process in the world. The Henriksdal wastewater treatment plant in Stockholm will be upgraded with an MBR, which will be able to treat 864000 $\mathrm{m}^{3} / \mathrm{d}$ of wastewater. The mentioned plant is the largest $\mathrm{MBR}$ plant in the world. In 2004, when the Nordkanal MBR plant was commissioned, it was the largest MBR plant having a design capacity of $45000 \mathrm{~m}^{3} / \mathrm{d}$. This increase in the treatment capacity between the Nordkanal and the Henriksdal plants shows the significant growth of MBR technology. ${ }^{118,119}$ In addition, membrane prices have significantly decreased during the last 15 years, and therefore, MBR technology has become a more attractive solution for medium-sized plants, having a population equivalent of 10000-100000. Furthermore, substantial progress has been accomplished in the design and operation optimization of MBR systems, which has helped to reduce the capital and operating costs of MBR plants. In 2008, a $22.4 \%$ compound annual growth rate was predicted for the world MBR market for the period 2008-2018. The global market for MBRs was $\$ 425.7$ million in 2014 and is projected to approach $\$ 777.7$ million by 2019 , registering a compound annual growth rate of $12.8 \%$ in the period 2014-2019. ${ }^{119}$

\section{Conclusions}

MBR can be effectively applied as a post treatment unit in pulp and paper wastewater treatment for the removal of organics, nutrients and microorganisms and its application is an emerging technology. With more studies being conducted on the MBR systems, this technology is an excellent alternative to conventional methods for industrial wastewater treatment so that clarified effluent could be produced. The application of MBR is necessary for long SRT, physical retention and subsequent hydrolysis to achieve the biological degradation of contaminants. New developments in this technology are expected to cause excellent solutions for treatment of recalcitrant industrial wastewater.

\section{Authors' Contributions}

All authors equally contributed to the present study.

Conflict of Interest Disclosures

The authors declare they have no conflicts of interest.

Acknowledgments

Present study was financially supported by grant No: 950704 of the Biotechnology Development Council of the Islamic Republic of Iran. 


\section{Reference}

1. Karrasch B, Parra O, Cid H, et al. Effects of pulp and paper mill effluents on the microplankton and microbial self-purification capabilities of the Biobio River, Chile. Sci Total Environ. 2006;359(1-3):194-208. doi:10.1016/j.scitotenv.2005.03.029.

2. Savant DV, Abdul-Rahman R, Ranade DR. Anaerobic degradation of adsorbable organic halides (AOX) from pulp and paper industry wastewater. Bioresour Technol. 2006;97(9):1092-1104. doi:10.1016/j.biortech.2004.12.013.

3. Ali M, Sreekrishnan TR. Aquatic toxicity from pulp and paper mill effluents: a review. Adv Environ Res. 2001;5(2):175-196. doi:10.1016/S1093-0191(00)00055-1.

4. Doble M, Kumar A. Biotreatment of industrial effluents. Elsevier; 2005.

5. Zwain HM, Hassan SR, Zaman NQ, Aziz HA, Dahlan I. The startup performance of modified anaerobic baffled reactor (MABR) for the treatment of recycled paper mill wastewater. J Environ Chem Eng. 2013;1(1-2):61-64. doi:10.1016/j.jece.2013.03.007.

6. Qu X, Gao WJ, Han MN, Chen A, Liao BQ. Integrated thermophilic submerged aerobic membrane bioreactor and electrochemical oxidation for pulp and paper effluent treatment--towards system closure. Bioresour Technol. 2012;116:1-8. doi:10.1016/j. biortech.2012.04.045.

7. Huang L, Cheng S, Rezaei F, Logan BE. Reducing organic loads in wastewater effluents from paper recycling plants using microbial fuel cells. Environ Technol. 2009;30(5):499-504. doi:10.1080/09593330902788244.

8. Eskelinen K, Sarkka H, Kurniawan TA, Sillanpaa MET. Removal of recalcitrant contaminants from bleaching effluents in pulp and paper mills using ultrasonic irradiation and Fenton-like oxidation, electrochemical treatment, and/or chemical precipitation: A comparative study. Desalination. 2010;255(1-3):179-187. doi:10.1016/j.desal.2009.12.024.

9. Liu T, Hu H, He Z, Ni Y. Treatment of poplar alkaline peroxide mechanical pulping (APMP) effluent with Aspergillus niger. Bioresour Technol. 2011;102(15):7361-7365. doi:10.1016/j. biortech.2011.04.043.

10. Avsar E, Demirer GN. Cleaner production opportunity assessment study in SEKA Balikesir pulp and paper mill. J Clean Prod. 2008;16(4):422-431. doi:10.1016/j.jclepro.2006.07.042.

11. Xie K, Lin HJ, Mahendran B, et al. Performance and fouling characteristics of a submerged anaerobic membrane bioreactor for kraft evaporator condensate treatment. Environ Technol. 2010;31(5):511-521. doi:10.1080/09593330903527898.

12. Khansorthong S, Hunsom M. Remediation of wastewater from pulp and paper mill industry by the electrochemical technique. Chem Eng J. 2009;151(1-3):228-234. doi:10.1016/j.cej.2009.02.038.

13. European Commission. Integrated Pollution Prevention and Control (IPPC)-Reference Document on Best Available Techniques in the Pulp and Paper Industry. http://eippcb.jrc.ec.europa.eu/ reference/BREF/sa_bref_0505.pdf. Published 2005.

14. Martin-Sampedro R, Eugenio ME, Villar JC. Biobleaching of Eucalyptus globulus kraft pulps: comparison between pulps obtained from exploded and non-exploded chips. Bioresour Technol. 2011;102(6):4530-4535. doi:10.1016/j. biortech.2010.12.090.

15. Kamali M, Khodaparast Z. Review on recent developments on pulp and paper mill wastewater treatment. Ecotoxicol Environ Saf. 2015;114:326-342. doi:10.1016/j.ecoenv.2014.05.005.

16. Vepsalainen M, Kivisaari H, Pulliainen M, Oikari A, Sillanpaa M. Removal of toxic pollutants from pulp mill effluents by electrocoagulation. Sep Purif Technol. 2011;81(2):141-150. doi:10.1016/j.seppur.2011.07.017

17. Ekstrand EM, Larsson M, Truong XB, et al. Methane potentials of the Swedish pulp and paper industry - A screening of wastewater effluents. Appl Energy. 2013;112:507-517. doi:10.1016/j. apenergy.2012.12.072.

18. Pokhrel D, Viraraghavan T. Treatment of pulp and paper mill wastewater--a review. Sci Total Environ. 2004;333(1-3):37-58. doi:10.1016/j.scitotenv.2004.05.017.

19. Nasser MS, Twaiq FA, Onaizi SA. Effect of polyelectrolytes on the degree of flocculation of papermaking suspensions. Sep Purif Technol. 2013;103:43-52. doi:10.1016/j.seppur.2012.10.024.

20. Holik H. Handbook of paper and board. John Wiley \& Sons; 2006.

21. van Beukering PJH, Bouman MN. Empirical evidence on recycling and trade of paper and lead in developed and developing countries. World Dev. 2001;29(10):1717-1737. doi:10.1016/ S0305-750X(01)00065-1.

22. Borchardt JK, Miller JD, Azevedo MAD. Office paper de-inking. Curr Opin Colloid Interface Sci. 1998;3(4):360-367. doi:10.1016/ S1359-0294(98)80050-2.

23. Zhenying S, Shijin D, Xuejun C, et al. Combined de-inking technology applied on laser printed paper. Chemical Engineering and Processing: Process Intensification. 2009;48(2):587-591. doi:10.1016/j.cep.2008.06.014.

24. Zhang X, Renaud S, Paice M. Cellulase deinking of fresh and aged recycled newsprint/magazines (ONP/OMG). Enzyme Microb Technol. 2008;43(2):103-108. doi:10.1016/j. enzmictec.2007.11.005.

25. Guedez AA, Puttmann W. Printing ink and paper recycling sources of TMDD in wastewater and rivers. Sci Total Environ. 2014;468469:671-676. doi:10.1016/j.scitotenv.2013.08.046.

26. Miranda R, Blanco A, Negro C. Accumulation of dissolved and colloidal material in papermaking-Application to simulation. Chem Eng J. 2009;148(2-3):385-393. doi:10.1016/j. cej.2008.09.014.

27. Izadi A, Hosseini M, Najafpour Darzi G, Nabi Bidhendi G, Pajoum Shariati F. Treatment of paper-recycling wastewater by electrocoagulation using aluminum and iron electrodes. J Environ Health Sci Eng. 2018;16(2):257-264. doi:10.1007/s40201-0180314-6.

28. Orrego R, Guchardi J, Krause R, Holdway D. Estrogenic and antiestrogenic effects of wood extractives present in pulp and paper mill effluents on rainbow trout. Aquat Toxicol. 2010;99(2):160167. doi:10.1016/j.aquatox.2010.04.016.

29. Singhal A, Thakur IS. Decolourization and detoxification of pulp and paper mill effluent by Emericella nidulans var. nidulans. J Hazard Mater. 2009;171(1-3):619-625. doi:10.1016/j. jhazmat.2009.06.041.

30. Izadi A, Hosseini M, Najafpour Darzi G, Nabi Bidhendi GR, Pajoum Shariati F. Paper-recycling wastewater treatment using Ocimum basilicum L. along with alum: Optimization by response surface methodology (RSM). Desalination Water Treat. 2018;116:205-213. doi:10.5004/dwt.2018.22483.

31. Berube PR, Hall ER. Effects of elevated operating temperatures on methanol removal kinetics from synthetic kraft pulp mill condensate using a membrane bioreactor. Water Res. 2000;34(18):4359-4366. doi:10.1016/S0043-1354(00)00203-7.

32. Dias JCT, Rezende RP, Silva CM, Linardi VR. Biological treatment of kraft pulp mill foul condensates at high temperatures using a membrane bioreactor. Process Biochem. 2005;40(3-4):11251129. doi:10.1016/j.procbio.2004.03.015.

33. Lerner M, Stahl N, Galil NI. Comparative study of MBR and activated sludge in the treatment of paper mill wastewater. Water Sci Technol. 2007;55(6):23-29. doi:10.2166/wst.2007.208.

34. Ashrafi O, Yerushalmi L, Haghighat F. Wastewater treatment in the pulp-and-paper industry: A review of treatment processes and the associated greenhouse gas emission. J Environ Manage. 2015;158:146-157. doi:10.1016/j.jenvman.2015.05.010.

35. Smith CV Jr, Di Gregorio D, Talcoltt RM. The use of ultrafiltration membrane for activated sludge separation, Proc. 24th Annual Purdue Industrial Waste Conf; 1968, pp. 1300-1310.

36. Cote $\mathrm{P}$, Buisson $\mathrm{H}$, Praderie $\mathrm{M}$. Immersed membranes activated sludge process applied to the treatment of municipal wastewater. Water Sci Technol. 1998;38(4-5):437-442. doi:10.1016/S02731223(98)00543-5. 
37. Bertanza G, Canato M, Laera G, Vaccari M, Svanstrom M, Heimersson S. A comparison between two full-scale MBR and CAS municipal wastewater treatment plants: technoeconomic-environmental assessment. Environ Sci Pollut Res Int. 2017;24(21):17383-17393. doi:10.1007/s11356-017-9409-3.

38. $\mathrm{Ng} \mathrm{ANL}$, Kim AS. A mini-review of modeling studies on membrane bioreactor (MBR) treatment for municipal wastewaters. Desalination. 2007;212(1-3):261-281. doi:10.1016/j. desal.2006.10.013.

39. Lyko S, Wintgens T, Al-Halbouni D, et al. Long-term monitoring of a full-scale municipal membrane bioreactor--Characterisation of foulants and operational performance. J Memb Sci. 2008;317(12):78-87. doi:10.1016/j.memsci.2007.07.008.

40. Harada H, Momonoi K, Yamazaki S, Takizawa S. Application of anaerobic-UF membrane reactor for treatment of a wastewater containing high strength particulate organics. Water Sci Technol. 1994;30(12):307-319. doi:10.2166/wst.1994.0630.

41. Mutamim NSA, Noor ZZ, Hassan MAA, Olsson G. Application of membrane bioreactor technology in treating high strength industrial wastewater: a performance review. Desalination. 2012;305:1-11. doi:10.1016/j.desal.2012.07.033.

42. Mutamim NSA, Noor ZZ, Hassan MAA, Yuniarto A, Olsson G. Membrane bioreactor: Applications and limitations in treating high strength industrial wastewater. Chem Eng J. 2013;225:109119. doi:10.1016/j.cej.2013.02.131.

43. Ng KK, Lin CF, Panchangam SC, Andy Hong PK, Yang PY. Reduced membrane fouling in a novel bio-entrapped membrane reactor for treatment of food and beverage processing wastewater. Water Res. 2011;45(14):4269-4278. doi:10.1016/j.watres.2011.05.031.

44. He Y, Xu P, Li C, Zhang B. High-concentration food wastewater treatment by an anaerobic membrane bioreactor. Water Res. 2005;39(17):4110-4118. doi:10.1016/j.watres.2005.07.030.

45. Kimura K, Hara H, Watanabe Y. Removal of pharmaceutical compounds by submerged membrane bioreactors (MBRs). Desalination. 2005;178(1-3):135-140. doi:10.1016/j. desal.2004.11.033.

46. Kim M, Guerra P, Shah A, Parsa M, Alaee M, Smyth SA. Removal of pharmaceuticals and personal care products in a membrane bioreactor wastewater treatment plant. Water Sci Technol. 2014;69(11):2221-2229. doi:10.2166/wst.2014.145.

47. Radjenovic J, Petrovic M, Barcelo D. Analysis of pharmaceuticals in wastewater and removal using a membrane bioreactor. Anal Bioanal Chem. 2007;387(4):1365-1377. doi:10.1007/s00216006-0883-6.

48. Munz G, Gori R, Cammilli L, Lubello C. Characterization of tannery wastewater and biomass in a membrane bioreactor using respirometric analysis. Bioresour Technol. 2008;99(18):86128618. doi:10.1016/j.biortech.2008.04.004.

49. Munz G, Gualtiero M, Salvadori L, Claudia B, Claudio L. Process efficiency and microbial monitoring in MBR (membrane bioreactor) and CASP (conventional activated sludge process) treatment of tannery wastewater. Bioresour Technol. 2008;99(18):8559-8564. doi:10.1016/j.biortech.2008.04.006.

50. Judd S. The MBR book: principles and applications of membrane bioreactors for water and wastewater treatment. Elsevier; 2010.

51. Ni Mhurchu J. Dead-end and crossflow microfiltration of yeast and bentonite suspensions: experimental and modelling studies incorporating the use of artificial neural networks. Dublin City University; 2008.

52. Le-Clech $\mathrm{P}$, Chen V, Fane TAG. Fouling in membrane bioreactors used in wastewater treatment. J Memb Sci. 2006;284(1):17-53. doi:10.1016/j.memsci.2006.08.019.

53. Liao B-Q, KraemerJT, Bagley DM. Anaerobic membranebioreactors: applications and research directions. Crit Rev Environ Sci Technol. 2006;36(6):489-530.doi:10.1080/10643380600678146.

54. Judd S. A review of fouling of membrane bioreactors in sewage treatment. Water Sci Technol. 2004;49(2):229-235. doi:10.2166/ wst.2004.0131.
55. Liao BQ, Bagley DM, Kraemer HE, Leppard GG, Liss SN. A review of biofouling and its control in membrane separation bioreactors. Water Environ Res. 2004;76(5):425-436. doi:10.2175/106143004X151527.

56. Fan Y, Li G, Wu L, et al. Treatment and reuse of toilet wastewater by an airlift external circulation membrane bioreactor. Process Biochem. 2006;41(6):1364-1370.doi:10.1016/j.procbio.2006.01.023.

57. Futselaar $H$, Schonewille $H$, de Vente $D$, Broens L. NORIT AirLift MBR: side-stream system for municipal waste water treatment. Desalination. 2007;204(1-3):1-7. doi:10.1016/j. desal.2006.02.027

58. Pajoom Shariati F, Bonakdarpour B, Mehrnia MR. Hydrodynamics and oxygen transfer behaviour of water in diesel microemulsions in a draft tube airlift bioreactor. Chemical Engineering and Processing: Process Intensification. 2007;46(4):334-342. doi:10.1016/j.cep.2006.07.003.

59. Pajoom Shariati F, Mehrnia MR, Madadkhah Salmasi B, Heran M, Wisniewski C, Sarrafzadeh MH. Membrane bioreactor for treatment of pharmaceutical wastewater containing acetaminophen. Desalination. 2010;250(2):798-800. doi:10.1016/j.desal.2008.11.044.

60. Hosseinzadeh M, Nabi-Bidhendi GR, Torabian A, Mehrdadi N. Evaluation of membrane bioreactor for advanced treatment of industrial wastewater and reverse osmosis pretreatment. J Environ Health Sci Eng. 2013;11(1):34. doi:10.1186/2052-336x-11-34.

61. Hosseinzadeh M, Nabi-Bidhendi GR, Torabian A, Mehrdadi N, Pourabdullah M. A new flat sheet membrane bioreactor hybrid system for advanced treatment of effluent, reverse osmosis pretreatment and fouling mitigation. Bioresour Technol. 2015;192:177-184. doi:10.1016/j.biortech.2015.05.066.

62. Rondon H, El-Cheikh W, Boluarte IA, et al. Application of enhanced membrane bioreactor (eMBR) to treat dye wastewater. Bioresour Technol. 2015;183:78-85. doi:10.1016/j.biortech.2015.01.110.

63. Nguyen NC, Chen SS, Nguyen HT, et al. Innovative sponge-based moving bed-osmotic membrane bioreactor hybrid system using a new class of draw solution for municipal wastewater treatment. Water Res. 2016;91:305-313. doi:10.1016/j.watres.2016.01.024.

64. Koltuniewicz AB, Drioli E. Membranes in clean technologies. Berlin: Wiley-VCH; 2008.

65. Radjenovic J, Matosic M, Mijatovic I, Petrovic M, Barcelo D. Membrane bioreactor (MBR) as an advanced wastewater treatment technology. In: Barcelo D, Petrovic M, eds. Emerging contaminants from industrial and municipal waste: removal technologies. Berlin, Heidelberg: Springer; 2008:37-101.

66. Zaviska F, Drogui P, Grasmick A, Azais A, Heran M Nanofiltration membrane bioreactor for removing pharmaceutical compounds. J Memb Sci. 2013;429:121-129. doi:10.1016/j. memsci.2012.11.022.

67. Hofs B, Ogier J, Vries D, Beerendonk EF, Cornelissen ER. Comparison of ceramic and polymeric membrane permeability and fouling using surface water. Sep Purif Technol. 2011;79(3):365374. doi:10.1016/j.seppur.2011.03.025.

68. Jin L, Ong SL, Ng HY. Comparison of fouling characteristics in different pore-sized submerged ceramic membrane bioreactors. Water Res. 2010;44(20):5907-5918. doi:10.1016/j. watres.2010.07.014.

69. Hanif SHBM. Fabrication of chitosan membrane: the effects of different polyethylene glycol compositions on membrane performance in oily wastewater treatment. Universiti Malaysia Pahang; 2008.

70. Judd SJ. The status of industrial and municipal effluent treatment with membrane bioreactor technology. Chem Eng J. 2016;305:3745. doi:10.1016/j.cej.2015.08.141.

71. Liao BQ, Xie K, Lin HJ, Bertoldo D. Treatment of kraft evaporator condensate using a thermophilic submerged anaerobic membrane bioreactor. Water Sci Technol. 2010;61(9):2177-2183. doi:10.2166/wst.2010.123.

72. Simstich B, Beimfohr C, Horn H. Lab scale experiments using a 
submerged MBR under thermophilic aerobic conditions for the treatment of paper mill deinking wastewater. Bioresour Technol. 2012;122:11-16. doi:10.1016/j.biortech.2012.04.029.

73. Vogelaar JCT. Thermophilic aerobic post treatment of anaerobically pretreated paper process water. Wageningen University; 2002.

74. Langevin SP, Liao BQ. Treatment of thermomechanical pulping condensate using thermophilic and mesophilic sequencing batch reactors. Water Sci Technol. 2010;62(11):2527-2535. doi:10.2166/ wst.2010.939.

75. Zhang Y, Ma C, Ye F, Kong Y, Li H. The treatment of wastewater of paper mill with integrated membrane process. Desalination. 2009;236(1-3):349-356. doi:10.1016/j.desal.2007.10.086.

76. Ragona CSF, Hall ER. Parallel operation of ultrafiltration and aerobic membrane bioreactor treatment systems for mechanical newsprint mill whitewater at $55^{\circ} \mathrm{C}$. Water Sci Technol. 1998;38(4):307-314. doi:10.1016/S0273-1223(98)00513-7.

77. Gommers K, De Wever H, Brauns E, Peys K. Recalcitrant COD degradation by an integrated system of ozonation and membrane bioreactor. Water Sci Technol. 2007;55(12):245-251. doi:10.2166/ wst.2007.410.

78. Lipnizki F. Membrane applications in the pulp and paper industry: Experience on lab, pilot and industrial scale. Desalination. 2006;199(1-3):159-160. doi:10.1016/j.desal.2006.03.160.

79. Galil NI, Levinsky Y. Sustainable reclamation and reuse of industrial wastewater including membrane bioreactor technologies: case studies. Desalination. 2007;202(1-3):411-417. doi:10.1016/j. desal.2005.12.081.

80. Minami K, Okamura K, Ogawa S, Naritomi T. Continuous anaerobic treatment of wastewater from a kraft pulp mill. J Ferment Bioeng. 1991;71(4):270-274.doi:10.1016/0922-338X(91)90280-T.

81. Minami K. A trial of high performance anaerobic treatment on wastewater from a kraft pulp mill. Desalination. 1994;98(1-3):273283. doi:10.1016/0011-9164(94)00152-9.

82. Gao WJJ, Lin HJ, Leung KT, Liao BQ. Influence of elevated $\mathrm{pH}$ shocks on the performance of a submerged anaerobic membrane bioreactor. Process Biochem. 2010;45(8):1279-1287. doi:10.1016/j.procbio.2010.04.018.

83. Meng F, Chae SR, Drews A, Kraume M, Shin HS, Yang F. Recent advances in membrane bioreactors (MBRs): membrane fouling and membrane material. Water Res. 2009;43(6):1489-1512. doi:10.1016/j.watres.2008.12.044.

84. Wang XM, Waite TD. Gel layer formation and hollow fiber membrane filterability of polysaccharide dispersions. J Memb Sci. 2008;322(1):204-213. doi:10.1016/j.memsci.2008.05.033.

85. Yang N, Wen X, Waite TD, Wang X, Huang X. Natural organic matter fouling of microfiltration membranes: Prediction of constant flux behavior from constant pressure materials properties determination. J Memb Sci. 2011;366(1-2):192-202. doi:10.1016/j. memsci.2010.10.003

86. Jarusutthirak C, Amy G. Role of soluble microbial products (SMP) in membrane fouling and flux decline. Environ Sci Technol. 2006;40(3):969-974. doi:10.1021/es050987a.

87. Liu Y, Fang HHP. Influences of extracellular polymeric substances (EPS) on flocculation, settling, and dewatering of activated sludge. Crit Rev Environ Sci Technol. 2003;33(3):237-273. doi:10.1080/10643380390814479.

88. Laspidou CS, Rittmann BE. A unified theory for extracellular polymeric substances, soluble microbial products, and active and inert biomass. Water Res. 2002;36(11):2711-2720. doi:10.1016/ S0043-1354(01)00413-4.

89. Rosenberger S, Evenblij H, te Poele S, Wintgens T, Laabs C. The importance of liquid phase analyses to understand fouling in membrane assisted activated sludge processes--six case studies of different European research groups. J Memb Sci. 2005;263(12):113-126. doi:10.1016/j.memsci.2005.04.010.

90. Rosenberger S, Laabs C, Lesjean B, et al. Impact of colloidal and soluble organic material on membrane performance in membrane bioreactors for municipal wastewater treatment. Water Res.
2006;40(4):710-720. doi:10.1016/j.watres.2005.11.028.

91. Erkan HS, Onkal Engin G, Ince M, Bayramoglu MR. Effect of carbon to nitrogen ratio of feed wastewater and sludge retention time on activated sludge in a submerged membrane bioreactor. Environ Sci Pollut Res Int. 2016;23(11):10742-10752. doi:10.1007/s11356016-6215-2.

92. Le-Clech $P$, Jefferson $B$, Judd SJ. Impact of aeration, solids concentration and membrane characteristics on the hydraulic performance of a membrane bioreactor. J Memb Sci. 2003;218(12):117-129. doi:10.1016/S0376-7388(03)00164-9.

93. Ping Chu H, Li XY. Membrane fouling in a membrane bioreactor (MBR): sludge cake formation and fouling characteristics. Biotechnol Bioeng. 2005;90(3):323-331. doi:10.1002/bit.20409.

94. Lesjean B, Rosenberger S, Laabs C, Jekel M, Gnirss R, Amy G. Correlation between membrane fouling and soluble/colloidal organic substances in membrane bioreactors for municipal wastewater treatment. Water Sci Technol. 2005;51(6-7):1-8. doi:10.2166/wst.2005.0615.

95. Pajoum Shariati F, Mehrnia MR, Sarrafzadeh MH, Rezaee S, Grasmick A, Heran M. Fouling in a novel airlift oxidation ditch membrane bioreactor (AOXMBR) at different high organic loading rate. Sep Purif Technol. 2013;105:69-78. doi:10.1016/j. seppur.2012.12.008.

96. Huang Z, Ong SL, Ng HY. Feasibility of submerged anaerobic membrane bioreactor (SAMBR) for treatment of low-strength wastewater. Water Sci Technol. 2008;58(10):1925-1931. doi:10.2166/wst.2008.749.

97. Krampe J, Krauth K. Oxygen transfer into activated sludge with high MLSS concentrations. Water Sci Technol. 2003;47(11):297303. doi:10.2166/wst.2003.0618.

98. Germain E, Nelles F, Drews A, et al. Biomass effects on oxygen transfer in membrane bioreactors. Water Res. 2007;41(5):10381044. doi:10.1016/j.watres.2006.10.020.

99. Judd $S$. The status of membrane bioreactor technology. Trends Biotechnol. 2008;26(2):109-116. doi:10.1016/j. tibtech.2007.11.005.

100. Huang Z, Ong SL, Ng HY. Submerged anaerobic membrane bioreactor for low-strength wastewater treatment: effect of HRT and SRT on treatment performance and membrane fouling. Water Res. 2011;45(2):705-713. doi:10.1016/j.watres.2010.08.035.

101. Xing $\mathrm{CH}$, Tardieu E, Qian Y, Wen XH. Ultrafiltration membrane bioreactor for urban wastewater reclamation. J Memb Sci. 2000;177(1-2):73-82. doi:10.1016/S0376-7388(00)00452-X.

102. Christensen ML, Bugge TV, Hede BH, Nierychlo M, Larsen P, Jorgensen MK. Effects of relaxation time on fouling propensity in membrane bioreactors. J Memb Sci. 2016;504:176-184. doi:10.1016/j.memsci.2016.01.006.

103. Chen J, Zhang M, Li F, et al. Membrane fouling in a membrane bioreactor: High filtration resistance of gel layer and its underlying mechanism. Water Res. 2016;102:82-89. doi:10.1016/j. watres.2016.06.028.

104. Charfi A, Thongmak N, Benyahia B, et al. A modelling approach to study the fouling of an anaerobic membrane bioreactor for industrial wastewater treatment. Bioresour Technol. 2017;245(Pt A):207-215. doi:10.1016/j.biortech.2017.08.003.

105. Chu L, Wang J, Wang B, et al. Changes in biomass activity and characteristics of activated sludge exposed to low ozone dose. Chemosphere. 2009;77(2):269-272. doi:10.1016/j. chemosphere.2009.07.047.

106. Sofia A, Ng WJ, Ong SL. Engineering design approaches for minimum fouling in submerged MBR. Desalination. 2004;160(1):67-74.

doi:10.1016/S0011-9164(04)90018-5.

107. Pajoum Shariati F, Heran M, Sarrafzadeh MH, et al. Biomass characterization by dielectric monitoring of viability and oxygen uptake rate measurements in a novel membrane bioreactor. Bioresour Technol. 2013;140:357-362. doi:10.1016/j. biortech.2013.04.099.

108. Song KG, Kim Y, Ahn KH. Effect of coagulant addition on 
membrane fouling and nutrient removal in a submerged membrane bioreactor. Desalination. 2008;221(1-3):467-474. doi:10.1016/j. desal.2007.01.107.

109. Rahimi $Y$, Torabian A, Mehrdadi N, Habibi-Rezaie M, Pezeshk $\mathrm{H}$, Nabi-Bidhendi GR. Optimizing aeration rates for minimizing membrane fouling and its effect on sludge characteristics in a moving bed membrane bioreactor. J Hazard Mater. 2011;186(23):1097-1102. doi:10.1016/j.jhazmat.2010.11.117.

110. Lebegue J, Aryal R, Shon HK, Vigneswaran S, Heran M, Grasmick A. Identification and quantification of foulant in submerged membrane reactor. Desalination and Water Treatment. 2010;24(13):278-283. doi:10.5004/dwt.2010.1624.

111. Choksuchart P, Heran M, Grasmick A. Ultrafiltration enhanced by coagulation in an immersed membrane system. Desalination. 2002;145(1-3):265-272. doi:10.1016/S0011-9164(02)00421-6.

112. Wu B, An Y, Li Y, Wong FS. Effect of adsorption/coagulation on membrane fouling in microfiltration process post-treating anaerobic digestion effluent. Desalination. 2009;242(1-3):183192. doi:10.1016/j.desal.2008.04.005.

113. Wong SS, Teng TT, Ahmad AL, Zuhairi A, Najafpour G. Treatment of pulp and paper mill wastewater by polyacrylamide (PAM) in polymer induced flocculation. J Hazard Mater. 2006;135(13):378-388. doi:10.1016/j.jhazmat.2005.11.076

114. Razali MAA, Ahmad Z, Ahmad MSB, Ariffin A. Treatment of pulp and paper mill wastewater with various molecular weight of polyDADMAC induced flocculation. Chem Eng J. 2011;166(2):529-535. doi:10.1016/j.cej.2010.11.011.

115. Kaya Y, Bacaksiz AM, Golebatmaz U, Vergili I, Gonder ZB, Yilmaz G. Improving the performance of an aerobic membrane bioreactor (MBR) treating pharmaceutical wastewater with powdered activated carbon (PAC) addition. Bioprocess Biosyst Eng. 2016;39(4):661-676. doi:10.1007/s00449-016-1547-3.

116. Akram A, Stuckey DC. Flux and performance improvement in a submerged anaerobic membrane bioreactor (SAMBR) using powdered activated carbon (PAC). Process Biochem. 2008;43(1):93-102. doi:10.1016/j.procbio.2007.10.020.

117. Hu AY, Stuckey DC. Activated carbon addition to a submerged anaerobic membrane bioreactor: effect on performance, transmembrane pressure, and flux. J Environ Eng. 2007;133(1):7380. doi:10.1061/(ASCE)0733-9372(2007)133:1(73).

118. Abass O, Wu X, Guo Y, Zhang K. Membrane bioreactor in China: a critical review. Int J Membr Sci Technol. 2015;2(2):29-47. doi:10.15379/2410-1869.2015.02.02.04.

119. Krzeminski P, Leverette L, Malamis S, Katsou E. Membrane bioreactors-a review on recent developments in energy reduction, fouling control, novel configurations, LCA and market prospects. J Memb Sci. 2017;527:207-227. doi:10.1016/j. memsci.2016.12.010. 